\title{
Fat and protein metabolism in growing steers fed either grass silage or dried grass
}

\author{
H. M. R. Greathead ${ }^{1}+\dagger$, J. M. Dawson ${ }^{1}$, J. Craigon ${ }^{1}$, V. A. Sessions ${ }^{1}$, N. D. Scollan ${ }^{2}$ and P. J. Buttery ${ }^{1}$ \\ ${ }^{1}$ Division of Nutritional Sciences, School of Biosciences, University of Nottingham, Sutton Bonington Campus, Loughborough, \\ Leicestershire, LE12 5RD, UK \\ ${ }^{2}$ Institute of Grassland and Environmental Research, Plas Gogerddan, Aberystwyth SY23 3EB, UK
}

(Received 5 July 2004 - Revised 31 May 2005 - Accepted 30 June 2005)

\begin{abstract}
Cattle fed grass silage diets have been reported to have high carcass fat:protein ratios. The effect of grass silage and dried grass diets, fed at different levels of intake to ensure a range of equivalent metabolisable energy intakes (MEI) from $1.1 \times$ metabolisable energy requirement for maintenance to ad libitum, on fat and protein metabolism in twenty-four Hereford $\times$ Friesian steers was investigated. After about $84 \mathrm{~d}$ of dietary treatment rates of whole-body fat and protein metabolism were measured, as were rates of lipogenesis in omental, perirenal and subcutaneous adipose tissue. Carcass composition was determined. Animals fed silage had greater $(P<0.001)$ carcass fat:protein ratios than animals fed dried grass at equivalent levels of MEI. Animals fed silage had lower $(P<0 \cdot 001)$ rates of protein gain. Rates of leucine entry and oxidation were lower $(P<0 \cdot 001)$ in animals fed silage, but there was no dietary difference in the rate of whole-body protein synthesis. There was no dietary difference in the rate of carcass fat gain, but rates of lipogenesis in perirenal adipose tissue were significantly $(P=0 \cdot 007)$ higher in animals fed silage. There was no dietary difference in the rate of palmitate and glycerol entry or palmitate oxidation. There were no interactions between MEI and diet, indicating that increments of energy were utilised with the same efficiency from both diets. It was concluded that the high carcass fat: protein ratios of young growing steers was due to limited rates of protein accretion and not to elevated rates of carcass fat accretion.
\end{abstract}

Ruminants: Grass silage: Dried grass: Fat metabolism: Protein metabolism: Carcass composition: Metabolisable energy

Grass silage forms the basis of many winter diets fed to beef cattle in the UK. The performance of animals fed silage is variable and often disappointing in terms of feed intake and the overall efficiency of energy (Thomas \& Chamberlain, 1990) and amino acid (Beever et al. 1992; MacRae et al. 1995) utilisation. It has been reported that animals fed silage have a high carcass fat:protein ratio (Lonsdale, 1976; Moore \& Steen, 1983; Baker et al. 1985, 1992; Steen \& Moore, 1988, 1989; Steen, 1991). That protein deposition is limited in animals fed grass silage is now well established (Gill et al. 1987). Whether or not fat deposition is increased in these animals is unclear.

With continuing pressures to increase the utilisation of grass in ruminant production systems, a greater understanding of the partition of nutrients between fat and protein deposition in animals fed grass silage is required if useful models to predict animal performance are to be developed. The objective of the present study was to determine whether or not an increased fat deposition contributes to the high carcass fat:protein ratio of animals fed grass silage by simultaneously investigating fat and protein metabolism, using isotope dilution and incorporation techniques, and carcass composition of young, growing steers fed either grass silage or dried grass. As both the quantity and form of metabolisable energy (ME) are considered to be important determinants of animal performance (Beever et al. 1988; Thomas \& Gill, 1988; Steen, 1992; Steen \& Robson, 1995), the animals were fed silage or dried grass at different levels of intake to ensure a range of equivalent ME intakes (MEI), based on the animals' estimated ME requirement for maintenance $\left(\mathrm{ME}_{\mathrm{m}}\right)$, with the objective of determining whether or not metabolism and carcass composition respond differentially to MEI from the two diets.

\section{Materials and methods \\ Animals and experimental design}

Thirty Hereford $\times$ Friesian steers were used, from which twenty-four were randomly selected and assigned a treatment in a 2 (diet: silage and dried grass) $\times 5$ (MEI: $1 \cdot 1,1 \cdot 2,1 \cdot 3$, 1.4 and $1.5 \times \mathrm{ME}_{\mathrm{m}}$ ) factorial experiment with two additional levels of dried grass MEI $\left(1.8\right.$ and $\left.2.0 \times \mathrm{ME}_{\mathrm{m}}\right)$, such that there were two steers per diet per MEI level. Animals were paired ensuring a minimal weight range between paired animals, and a similar weight range across dietary treatments. The six remaining steers were slaughtered at the start of

Abbreviations: IGF-I, insulin-like growth factor 1; KKCF, kidney knob and channel fats; LW, live weight; MADF, modified acid detergent fibre; ME, metabolisable energy; MEI, ME intake; $\mathrm{ME}_{\mathrm{m}}$, ME requirement for maintenance; Ra, rate of appearance.

* Corresponding author: Dr Henry Greathead, fax +44 113 3433063, email H.M.R.Greathead@leeds.ac.uk

$\dagger$ Present address: School of Biology, University of Leeds, Leeds LS2 9JT, UK. 
the experiment for carcass composition analysis (initial slaughter group).

The animals fed silage at $1.5 \times \mathrm{ME}_{\mathrm{m}}$ and dried grass at $2.0 \times \mathrm{ME}_{\mathrm{m}}$ were actually fed to appetite (fed $10 \%$ in excess of the previous day's refusals), with these intake levels representing the average ad libitum intakes of the animal in each pair with the highest intake over the experimental period. Animals fed dried grass at $1.5 \times \mathrm{ME}_{\mathrm{m}}$ were restricted to the voluntary MEI level of their silage-fed pair.

From weaning until the start of the experiment (approximately 5 weeks), the steers were group-penned on straw and fed Calf Starter (BOCM Pauls plc, Ipswich, Suffolk, UK) and hay. During this period the average live weight (LW) gain of the animals was $0.42(\mathrm{SD} 0 \cdot 11) \mathrm{kg} / \mathrm{d}$. At the start of the experiment the steers were approximately 13 weeks of age (mean LW: $94.2($ SD 7.2) $\mathrm{kg}$ ). The steers were penned individually on rubber matting. The experimental period lasted approximately 13 weeks with all cattle spending the final 2 weeks in metabolism crates. During the whole duration of the experiment, except when animals were in the metabolism crates, steers were weighed twice weekly and their dietary intakes adjusted accordingly. They were fed equal-sized meals twice daily, and had free access to water and mineral licks (Standard Wright Blocks; Frank Wright Ltd, Ashbourne, Derbyshire, UK) at all times.

Once in metabolism crates steers were not weighed. Dietary feeding levels were adjusted according to previous rates of LW gain using linear regression. Final LW was determined in the same way. Diets were fed hourly using automatic feeders. The steers were allowed a $7 \mathrm{~d}$ adjustment period to the metabolism crates before the start of metabolism measurements, involving three intravenous infusions of isotope over a period of $4 \mathrm{~d}$ : $\left[1-{ }^{13} \mathrm{C}\right]$ leucine, a combined $\left[1-{ }^{13} \mathrm{C}\right]$ palmitate and $\left[2-{ }^{3} \mathrm{H}\right]$ glycerol infusion, and a combined $\mathrm{NaH}^{13} \mathrm{CO}_{3}$ and $\left[1-{ }^{14} \mathrm{C}\right]$ acetate infusion. On the eleventh day in metabolism crates the steers were slaughtered.

The experiment was carried out under licence of the Animals (Scientific Procedures) Act, 1986.

\section{Diets}

Big bale silage made from unchopped, unwilted primary growth perennial ryegrass (Lolium perenne $\mathrm{cv}$. Cropper) was used. The silage was prepared on the same day from a single sward. The dried grass had been chopped, artificially dried and pelleted, and all came from the same batch. The modified acid detergent fibre (MADF) and DM contents of each bale of silage and the dried grass were determined prior to feeding. Silage bales of similar MADF and DM composition were selected for use in the experiment. The MADF values were used to estimate dietary ME values (Agriculture and Food Research Council, 1993). During the experiment samples (approximately $0.5 \mathrm{~kg}$ ) of silage and dried grass were taken daily. These samples were pooled over weekly intervals, mixed thoroughly, sub-sampled (approximately $0.5 \mathrm{~kg}$ ) and stored until analysed. Silage samples were refrigerated (approximately $4^{\circ} \mathrm{C}$ ) until pooled and then frozen (approximately $-20^{\circ} \mathrm{C}$ ), and dried grass samples were stored at room temperature until analysed.

The desired levels of MEI were achieved by changing the total amount of feed provided rather than by changing the composition of the diets. Feed intake levels were determined based on the steers' estimated $\mathrm{ME}_{\mathrm{m}}$, which were calculated using the equation:

$$
\mathrm{ME}_{\mathrm{m}}(\mathrm{MJ} / \mathrm{d})=\frac{(\mathrm{LW} \times 0 \cdot 061)+5 \cdot 67}{k_{\mathrm{m}}},
$$

where $k_{\mathrm{m}}$ is the efficiency with which ME is used for maintenance and was assumed to be 0.72 (Agriculture and Food Research Council, 1993). The intakes of DM, ME and total $\mathrm{N}$ used in this analysis are the average intakes recorded over the period prior to entering metabolism crates.

\section{Preparation of infusates}

$\left[1-{ }^{13} \mathrm{C}\right]$ Leucine. The $\left[1-{ }^{13} \mathrm{C}\right]$ leucine $\left(99 \cdot 3\right.$ atom $\%{ }^{13} \mathrm{C}$; MassTrace Inc., Woburn, MA, USA) infusate $\left(3 \cdot 3 \mu \mathrm{g}\left[1-{ }^{13} \mathrm{C}\right]\right.$ leucine/kg LW per $\mathrm{ml}$ infused at $2 \mathrm{ml} / \mathrm{min}$ ) and priming dose $(393 \mu \mathrm{g} / \mathrm{kg}$ LW) were prepared as described by Dawson et al. (1998).

$\left[1-{ }^{13} \mathrm{C}\right]$ Palmitate and $\left[2-{ }^{3} \mathrm{H}\right]$ glycerol. The $\left[1-{ }^{13} \mathrm{C}\right]$ palmitate (99 atom\% ${ }^{13} \mathrm{C}$; MassTrace Inc.) infusate $\left(2 \cdot 5 \mu \mathrm{g}\left[1-{ }^{13} \mathrm{C}\right] \mathrm{pal}-\right.$ mitate/kg LW per $\mathrm{ml}$ infused at $2 \mathrm{ml} / \mathrm{min}$ ) was prepared as described by Dawson et al. (1998). To this was added $\left[2{ }^{3} \mathrm{H}\right]$ glycerol $\quad(355 \mathrm{GBq} / \mathrm{mmol}$; ICN Biomedicals Ltd, Thame, Oxfordshire, UK) such that the final specific radioactivity of the infusate was $0.23 \mathrm{kBq} / \mathrm{kg} \mathrm{LW}$ per ml.

$\mathrm{NaH}^{13} \mathrm{CO}_{3}$ and $\left[1{ }^{14}\right.$ C]acetate. The $\mathrm{NaH}^{13} \mathrm{CO}_{3}$ infusate $\left(8.0 \mu \mathrm{g} \mathrm{NaH}{ }^{13} \mathrm{CO}_{3} /(\mathrm{kg} \mathrm{LW})^{0.75}\right.$ per $\mathrm{ml}$ infused at $\left.2 \mathrm{ml} / \mathrm{min}\right)$ was prepared in saline bags $(0.9 \%$ (w/v) NaCl; Baxter Healthcare Ltd, Thetford, Norfolk, UK). $\mathrm{NaH}^{13} \mathrm{CO}_{3}$ (99 atom\% ${ }^{13} \mathrm{C}$; MassTrace Inc.) was dissolved in a small volume of saline removed from the saline bag and the resulting solution filter-sterilised $(0.2 \mu \mathrm{m}$ Minisart syringe filter; Sartorius $\mathrm{GmbH}$, Göttingen, Germany) as it was returned back to the saline bag. To this was added $\left[1-{ }^{14} \mathrm{C}\right]$ acetate $(2 \cdot 2 \mathrm{GBq} /$ mmol; ICN Pharmaceuticals Ltd, Thame, Oxfordshire, UK) such that the final infusate specific radioactivity of $\left[1-{ }^{14} \mathrm{C}\right]$ acetate was $0.5 \mathrm{kBq} / \mathrm{kg} \mathrm{LW}$ per $\mathrm{ml}$.

Priming doses of $\mathrm{NaH}^{13} \mathrm{CO}_{3}$ were administered immediately before the start of the $\left[1-{ }^{13} \mathrm{C}\right]$ leucine, the combined $\left[1-{ }^{13} \mathrm{C}\right]$ palmitate/[2- $\left.{ }^{3} \mathrm{H}\right]$ glycerol $\quad\left(106 \cdot 3 \mu \mathrm{g} \quad \mathrm{NaH}^{13} \mathrm{CO}_{3} / \mathrm{kg}\right.$ $\mathrm{LW})$ and the combined $\mathrm{NaH}^{13} \mathrm{CO}_{3} /\left[1{ }^{14} \mathrm{C}\right]$ acetate $(1.36 \mathrm{mg}$ $\left.\mathrm{NaH}^{13} \mathrm{CO}_{3} /(\mathrm{kg} \mathrm{LW})^{0.75}\right)$ infusions. Priming doses were prepared in $20 \mathrm{ml}$ saline and then filter-sterilised $(0.2 \mu \mathrm{m}$ Minisart syringe filter).

Priming doses of $\mathrm{NaH}^{13} \mathrm{CO}_{3}$ and $\left[1-{ }^{13} \mathrm{C}\right]$ leucine were administered to ensure that stable equilibrium ${ }^{13} \mathrm{C}$-enrichments were rapidly achieved for expired $\mathrm{CO}_{2}$ and plasma leucine, respectively, due to the slower fractional turnover rates of the plasma $\mathrm{NaHCO}_{3}$ (Allsop et al. 1978) and leucine (Matthews et al. 1980) pools.

Precautions for the use of radioactive isotopes towards humans subjects, animals and the environment were those stipulated in the University of Nottingham's Code of Practice.

\section{Experimental procedures}

On the fourth day that steers were in metabolism crates, both of their jugular veins were fitted with indwelling cannulae and 
kept patent by daily flushing with $3 \cdot 8 \%(\mathrm{w} / \mathrm{v})$ tri-sodium citrate in sterile saline $(0.9 \% \mathrm{NaCl})$.

On the eighth day in metabolism crates the steers received a $\mathrm{NaH}^{13} \mathrm{CO}_{3^{-}}$and $\left[1{ }^{13} \mathrm{C}\right]$ leucine-primed $6 \mathrm{~h}$ continuous intravenous infusion of $\left[1-{ }^{13} \mathrm{C}\right]$ leucine to determine the rate of appearance $(\mathrm{Ra})$ of plasma leucine and the rate of leucine oxidation.

On the ninth day in metabolism crates each steer received a $\mathrm{NaH}^{13} \mathrm{CO}_{3}$-primed $6 \mathrm{~h}$ continuous intravenous infusion of $\left[1-{ }^{13} \mathrm{C}\right]$ palmitate and $\left[2-{ }^{3} \mathrm{H}\right]$ glycerol, for determination of the $\mathrm{Ra}$ of plasma palmitate and the rate of palmitate oxidation, and determination of the Ra of plasma glycerol, respectively. A $1 \mathrm{~d}$ 'rest period' followed to allow clearance of residual ${ }^{13} \mathrm{C}$ label remaining from the previous infusions.

On the eleventh day in metabolism crates each steer received a combined, $\mathrm{NaH}^{13} \mathrm{CO}_{3}$-primed, $6 \mathrm{~h}$ continuous intravenous infusion of $\mathrm{NaH}^{13} \mathrm{CO}_{3}$ and $\left[1-{ }^{14} \mathrm{C}\right]$ acetate, for determination of the $\mathrm{Ra}$ of whole-body $\mathrm{CO}_{2}$ and rates of acetate incorporation into lipid, respectively. At the end of the $6 \mathrm{~h}$ infusion the steers were killed with a lethal dose of pentobarbitone (Euthesate ${ }^{\circledR}, 200 \mathrm{~g}$ pentabarbitone sodium/l; Williams Francis Veterinary, Crawley, West Sussex, UK) and exsanguinated. Adipose tissue samples from the subcutaneous (tailhead region), omental and perirenal depots were taken within 2 min of death. The carcass was then dressed, weighed and halved.

Samples of blood and breath were taken at $30 \mathrm{~min}$ intervals for a period of $2 \mathrm{~h}$ before the start of the infusions, for the determination of background levels of isotope. Following the start of the infusions breath samples were taken at $15 \mathrm{~min}$ intervals for the first $2 \mathrm{~h}$, and then at $30 \mathrm{~min}$ intervals until the end of the infusions; blood samples were taken at $30 \mathrm{~min}$ intervals throughout the infusions. Blood samples taken on the day of the combined $\left[1-{ }^{13} \mathrm{C}\right]$ palmitate/[2- $\left.{ }^{3} \mathrm{H}\right]$ glycerol infusion were collected into tubes containing K-EDTA $(15 \mu \mathrm{g} / \mathrm{ml}$ blood $)$. All other blood samples were collected into tubes containing heparin (25 units $/ \mathrm{ml}$ blood). Plasma was isolated from the blood samples by centrifuging at $1000 \mathrm{~g}$ for $15 \mathrm{~min}$, which was then stored in a freezer (approximately $-20^{\circ} \mathrm{C}$ ) until analysed.

Breath samples were collected into 2-litre breath bags, fitted with one-way valves, via a facemask that was placed over the animal's nostrils. Triplicate samples of breath were drawn from the bag into evacuated tubes and stored at room temperature until analysed.

Adipose tissue samples were prepared as described by Greathead et al. (2001). From both halves of the dressed carcass, the kidney knob and channel fats (KKCF) were dissected, pooled and weighed. The longissimus dorsi and semitendinosus muscles were dissected from the left half of the carcass and weighed. The entire right half of the carcass (excluding the kidney and $\mathrm{KKCF}$ ) was weighed and then frozen (approximately $-20^{\circ} \mathrm{C}$ ) for subsequent compositional analysis.

\section{Analytical methods}

Dietary analysis. The chemical composition of the silage and dried grass were determined as described by Scollan et al. (2001).

Plasma palmitate ${ }^{13}$ C-enrichment and concentration. These were determined by a modified version of the method described by Hachey et al. (1991). The modification involved substitution of the derivatising agent pentafluorobenzyl bromide with iodomethane such that fatty acid methyl esters rather than pentafluorobenzyl esters were formed, enabling analysis by electron impact-GC/MS.

Plasma NEFA concentration. These were determined colorimetrically using a commercially available assay kit (NEFA-C, Wako \#994-75 409; Alpha Laboratories, Eastleigh, Hampshire, UK).

Plasma leucine and ketoisocaproic acid ${ }^{13}$ C-enrichment and concentration. Using the method described by Calder \& Smith (1988), amino acids and keto acids were first isolated from plasma, then transformed to t-butyldimethylsilyl and quinoxalinol-t-butyldimethylsilyl derivatives respectively, and finally analysed by electron impact-GC/MS.

Breath ${ }^{13} \mathrm{CO}_{2}$-enrichment. The ${ }^{13} \mathrm{C}$-enrichment of expired air was determined with a Europa Scientific Tracermass IRMS (Europa Scientific, Crewe, Cheshire, UK). Breath samples were introduced to the isotope ratio mass spectrometer using Roboprep-G (Europa Scientific). Samples were measured against a standard reference gas of $5 \% \mathrm{CO}_{2}$ in air of known ${ }^{13} \mathrm{C}$-enrichment.

Specific radioactivity of plasma glycerol. Plasma samples were deproteinised with perchloric acid (6\%, v/v) according to the method of Somogyi (1945). The concentration of glycerol in the deproteinised plasma was measured spectrophotometrically using a commercial glycerol assay kit (catalogue no. 148270; Boehringer Mannheim GmbH, Mannheim, Germany). The specific radioactivity of deproteinised plasma glycerol was determined using a modified version of the method described by Symonds et al. (1989), which involved using Dowex $1\left(\mathrm{OH}^{-}\right.$form, 200-400 mesh) ion-exchange resin to trap glucose in place of Dowex 1 (borate form, 200-400 mesh).

\section{Specific radioactivity of plasma acetate, and total lipid extraction and specific radioactivity determination from adipose tissue}

These were determined using methods described by Greathead et al. (2001).

Plasma insulin concentration. Plasma insulin concentrations were measured using a commercially available RIA kit (INS-RIA-100; Lifescreen Ltd, Watford, Hertfordshire, UK). Chemical composition analysis of carcass and muscle samples. This was determined using methods described by Gibb \& Baker (1992).

\section{Calculations}

Initial carcass composition and live weight gains. Gains in carcass weight and its chemical components were calculated as the difference between the measured component at slaughter and the initial value estimated from regression analysis (Table 1) on the values derived from the initial slaughter group. The mean LW of the initial slaughter group at slaughter was 94.7 (SD 10.10) kg. The average LW gains of the steers were determined by linear regression using the twice-weekly measured LW of the steers.

Rates of appearance, oxidation, whole-body protein synthesis and acetate incorporation into lipid. In all cases, 
Table 1. Constants $(\alpha)$ and coefficients $(\beta)$ from the regression of carcass weight $(\mathrm{kg})$ and the chemical components $(\mathrm{kg})$ of the carcass $v$. live weight $(\mathrm{kg})$ of the initial slaughter group of steers

(Mean values with their standard errors)

\begin{tabular}{|c|c|c|c|c|c|c|}
\hline & \multicolumn{2}{|c|}{$\alpha$} & \multicolumn{2}{|c|}{$\beta$} & \multirow[b]{2}{*}{$r^{2}$} & \multirow{2}{*}{$\begin{array}{l}\text { RSD } \\
(n 6)\end{array}$} \\
\hline & Mean & SE & Mean & SE & & \\
\hline Carcass weight & 4.4 & 7.06 & 0.46 & 0.074 & 0.88 & 1.68 \\
\hline Crude protein & -0.2 & $2 \cdot 21$ & 0.10 & 0.023 & 0.77 & 0.53 \\
\hline Fat & $-3 \cdot 1$ & 1.09 & 0.07 & 0.011 & 0.87 & 0.26 \\
\hline Ash & 0.7 & 0.479 & 0.02 & 0.005 & 0.81 & 0.11 \\
\hline Water & $6 \cdot 6$ & 4.90 & 0.28 & 0.052 & 0.85 & $1 \cdot 16$ \\
\hline
\end{tabular}

RSD, residual standard deviation.

For details of animals and procedures, see p. 28.

stable equilibrium ${ }^{13} \mathrm{C}$ - and ${ }^{14} \mathrm{C}$-enrichments were achieved within $2 \mathrm{~h}$ of the start of the continuous infusions.

The rates of appearance of palmitate and total-body $\mathrm{CO}_{2}$ were calculated by dividing the infusion rate of the tracers $\left[1-{ }^{13} \mathrm{C}\right]$ palmitate and $\mathrm{NaH}^{13} \mathrm{CO}_{3}$ respectively, by the tracer: tracee ratios of palmitate and $\mathrm{NaHCO}_{2}$ (measured as breath $\mathrm{CO}_{2}$ ) respectively, at isotopic equilibrium. Tracer:tracee ratios were determined as described by Dawson et al. (1999).

The rate of plasma leucine appearance was calculated using the equation described by Wolfe et al. (1980). The plasma ${ }^{13} \mathrm{C}$-enrichment of ketoisocaproic acid rather than leucine was used in the equation on the assumption that it more accurately reflects the true intracellular precursor pool enrichment (Matthews et al. 1982).

Rates of plasma glycerol and acetate appearance were calculated by dividing the infusion rate of the labelled substrate, $\left[1-{ }^{14} \mathrm{C}\right]$ glycerol and $\left[1-{ }^{14} \mathrm{C}\right]$ acetate respectively, by the specific radioactivity of the substrate at isotopic equilibrium (Pethick \& Dunshea, 1993).

The oxidation rates of palmitate and leucine were calculated using the equation:

$$
\text { Oxidation rate }\left(\mu \mathrm{mol} / \mathrm{min} \text { per } \mathrm{kg}^{0.75}\right)=\frac{\mathrm{APE}_{\mathrm{CO}_{2}} \times \mathrm{Ra}_{\mathrm{CO}_{2}}}{\mathrm{APE}_{\mathrm{S}}} \text {, }
$$

where $\mathrm{APE}_{\mathrm{CO} 2}$ is the isotopic enrichment of expired $\mathrm{CO}_{2}$ at isotopic equilibrium measured during the continuous infusion of $\left[1-{ }^{13} \mathrm{C}\right]$ palmitate or $\left[1-{ }^{13} \mathrm{C}\right]$ leucine, respectively; $\mathrm{Ra}_{\mathrm{CO} 2}$ is the rate of appearance of total-body $\mathrm{CO}_{2}$; and $\mathrm{APE}_{\mathrm{S}}$ is the plasma isotopic enrichment of $\left[1-{ }^{13} \mathrm{C}\right]$ palmitate or $\left[{ }^{13} \mathrm{C}\right] \mathrm{ketoi}-$ socaproic acid, respectively, at isotopic equilibrium depending on which substrate oxidation rate is being calculated.

Rates of whole-body protein synthesis were calculated using the equation (Krishnamurti \& Janssens, 1988):

$$
\begin{aligned}
& \text { Protein synthesis }\left(\mathrm{g} /(\mathrm{kg} \mathrm{LW})^{0.75} \text { per } \mathrm{d}\right) \\
& =\frac{\left(\mathrm{Ra}_{\text {leucine }}-\text { leucine oxidation }\right)}{0.081} \times 0.189,
\end{aligned}
$$

where 0.081 is the average leucine concentration ( $\mathrm{g} / \mathrm{g}$ protein) in cattle carcass protein (Food and Agricultural Organization, 1970 ), and $0 \cdot 189$ converts from $\mu \mathrm{mol} / \mathrm{min}$ to $\mathrm{g} / \mathrm{d}$.

The rate of acetate incorporation into adipose tissue lipid $\left(\mathrm{R}_{\text {lipid }}\right)$ was calculated from the increase in accumulation of
${ }^{14} \mathrm{C}$-label in the total lipid over time as described by Greathead et al. (2001).

All rates of metabolism were expressed relative to the animals' metabolic LW $\left(\mathrm{kg}^{0.75}\right)$.

\section{Statistical analysis}

Data were analysed by multiple linear regression using Genstat for Windows (Release 6.1; Lawes Agricultural Trust, Rothamstead, Hertfordshire, UK). Data were initially fitted to the model:

$$
\begin{aligned}
Y= & \alpha+\beta_{1} M E I+\beta_{2} \text { Diet }+\beta_{3} M E I \cdot \text { Diet }+\beta_{4} M E I^{2} \\
& +\beta_{5} M E I^{2} \cdot \text { Diet },
\end{aligned}
$$

where $Y$ was the response variable, $\alpha$ was a constant, $\beta_{1}, \ldots, \beta_{5}$ were regression coefficients, $M E I$ and $M E I^{2}$ were the explanatory variables and Diet was the indicator variable. As the quadratic terms $M E I^{2}$ and $M E I^{2}$.Diet, and the linear interaction term $M E I \cdot D i e t$, did not improve the fit of the model they were excluded from the final model. However, the $P$ values for the linear interaction term MEI Diet, when included in the model, are presented for the purpose of illustrating the lack of a differential dietary response to MEI. Residuals were examined for homogeneity of variance and normality. As actual MEI differed from the planned MEI, the fitted model was used to predict responses at the planned levels of MEI, and comparisons between the two diets at the planned MEI were made by $t$ test using the standard errors for the predicted response values and the residual degrees of freedom from the regression.

\section{Results}

\section{Chemical composition of the silage and dried grass}

The silage composition data presented (Table 2) are the average composition for all bales used. The silage had a DM content of $282.9 \mathrm{~g} / \mathrm{kg}$ fresh weight and a total $\mathrm{N}$ content of $33.5 \mathrm{~g} / \mathrm{kg} \mathrm{DM}$, of which $10.8 \%$ was $\mathrm{NH}_{3}-\mathrm{N}$. The iso- and n-butyric acid contents were low at 0.27 and $0.29 \mathrm{~g} / \mathrm{kg} \mathrm{DM}$, respectively. Lactic acid $(50.6 \mathrm{~g} / \mathrm{kg} \mathrm{DM})$ content was low whilst acetic acid $(26.7 \mathrm{~g} / \mathrm{kg} \mathrm{DM})$ content was considered to be relatively high. On the basis of these values the silage was considered to be of poor quality. This was reflected in the ad libitum $\left(1.5 \times \mathrm{ME}_{\mathrm{m}}\right) \mathrm{DM}$ intake $(21.4 \mathrm{~g} / \mathrm{kg} \mathrm{LW}$ per $\mathrm{d}$, Table 3) and daily LW gain (0.4 (SD 0.02) kg/d, Table 4) of the animals fed silage, which were considered to be average and poor, respectively.

The dried grass had a lower total $\mathrm{N}$ content $(28.4 \mathrm{~g}$ total $\mathrm{N} / \mathrm{kg} \mathrm{DM}$ ), but the insoluble $\mathrm{N}$ content was much greater than that of the silage $(811 v .349 \mathrm{~g} / \mathrm{kg}$ total $\mathrm{N})$. The ME content, calculated from MADF content, was slightly higher for the dried grass $(10 \cdot 8 \mathrm{MJ} / \mathrm{kg} \mathrm{DM})$ than for the silage $(10 \cdot 4 \mathrm{MJ} / \mathrm{kg} \mathrm{DM})$. The dried grass, compared with the sil age, had a considerably higher content of water-soluble carbohydrate $(149.6$ v. $11.5 \mathrm{~g} / \mathrm{kg} \mathrm{DM})$. The fact that starch was present in the silage $(7.6 \mathrm{~g} / \mathrm{kg} \mathrm{DM})$ was somewhat surprising, as temperate grasses, unlike tropical grasses, are believed to not accumulate starches (McDonald et al. 1991). This result 
Table 2. Chemical composition ( $\mathrm{g} / \mathrm{kg} \mathrm{DM}$ ) of the silage and dried grass diets

(Mean values and standard deviations for twenty-six samples)

\begin{tabular}{|c|c|c|c|}
\hline & \multicolumn{2}{|c|}{ Silage } & \multirow[b]{2}{*}{ Dried grass } \\
\hline & Mean & SD & \\
\hline DM (g/kg fresh diet) & $282.9 \dagger$ & $36 \cdot 0$ & $916 \cdot 8$ \\
\hline Organic matter & 914 & $8 \cdot 0$ & 914.9 \\
\hline Total N & 33.5 & $3 \cdot 3$ & $28 \cdot 4$ \\
\hline Ammonia-N (g/kg total $N$ ) & $107 \cdot 8$ & $14 \cdot 4$ & \\
\hline Soluble $N(\mathrm{~g} / \mathrm{kg}$ total $\mathrm{N})$ & 651.4 & $54 \cdot 8$ & $187 \cdot 7$ \\
\hline Insoluble N (g/kg total N) & $348 \cdot 6$ & $54 \cdot 8$ & $810 \cdot 9$ \\
\hline Ash & $86 \cdot 0$ & $8 \cdot 0$ & $85 \cdot 1$ \\
\hline Neutral detergent fibre & $529 \cdot 4$ & $25 \cdot 6$ & $536 \cdot 7$ \\
\hline Acid detergent fibre & $326 \cdot 1$ & $19 \cdot 9$ & $270 \cdot 9$ \\
\hline Modified acid detergent fibre & $330 \cdot 4$ & $18 \cdot 7$ & 271 \\
\hline Acid detergent fibre- $\mathrm{N}$ & 0.9 & 0.3 & $2 \cdot 7$ \\
\hline Starch & $7 \cdot 6$ & $3 \cdot 1$ & $25 \cdot 1$ \\
\hline Water-soluble carbohydrate & 11.5 & $4 \cdot 0$ & $149 \cdot 6$ \\
\hline Lactic acid & $50 \cdot 6$ & $10 \cdot 77$ & \\
\hline Acetic acid & $26 \cdot 7$ & $13 \cdot 24$ & \\
\hline Propionic acid & 1.06 & 0.70 & \\
\hline iso-Butyric acid & $0 \cdot 27$ & $0 \cdot 19$ & \\
\hline n-Butyric acid & 0.29 & 0.54 & \\
\hline iso-Valeric acid & 0.04 & 0.07 & \\
\hline n-Valeric acid & 0.02 & 0.07 & \\
\hline Gross energy (MJ/kg DM) & $18 \cdot 9$ & 0.3 & $18 \cdot 7$ \\
\hline Metabolisable energy (MJ/kg DM)* & $10 \cdot 4$ & 0.25 & $10 \cdot 8$ \\
\hline $\mathrm{pH}$ & $4 \cdot 38$ & $0 \cdot 10$ & \\
\hline Buffering capacity (meq/kg DM) & $770 \cdot 9$ & $179 \cdot 6$ & \\
\hline
\end{tabular}

*Estimated from modified acid detergent fibre.

†Toluene DM, corrected for ethanol content.

For details of diets and procedures, see p. 28.

is likely to be indicative of contamination with water-soluble carbohydrates.

\section{Dietary intakes}

The experiment was designed to provide silage or dried grass to animals over a range of, and where possible, equivalent MEI, from $1.1 \times \mathrm{ME}_{\mathrm{m}}$ to ad libitum. The average recorded MEI of the animals in the different treatment groups closely matched the planned MEI levels, with the exception of the ad libitum MEI levels, where intakes were more variable (Table 3).

As the concentration of ME in the silage was approximately 0.96 that of the dried grass (Table 2), animals were fed proportionately less dried grass DM than animals fed silage at equivalent levels of MEI. Consequently, animals fed silage had higher $(P<0.001)$ recorded total $\mathrm{N}$ intakes than animals fed dried grass at equivalent levels of MEI. However, animals fed dried grass had approximately $85 \%$ higher intakes of insoluble $\mathrm{N}$ than animals fed silage at equivalent levels of MEI. Water-soluble carbohydrate intakes for the silage diets were only approximately $8 \%$ of those for the dried grass diets at equivalent MEI. Therefore, over the MEI range of $1 \cdot 1-$ $1.5 \times \mathrm{ME}_{\mathrm{m}}$, intakes of insoluble $\mathrm{N}$ and water-soluble carbohydrate differed markedly.

At ad libitum levels of intake there was no difference $(P>0.05)$ in the mean recorded DM intake between the two diets.

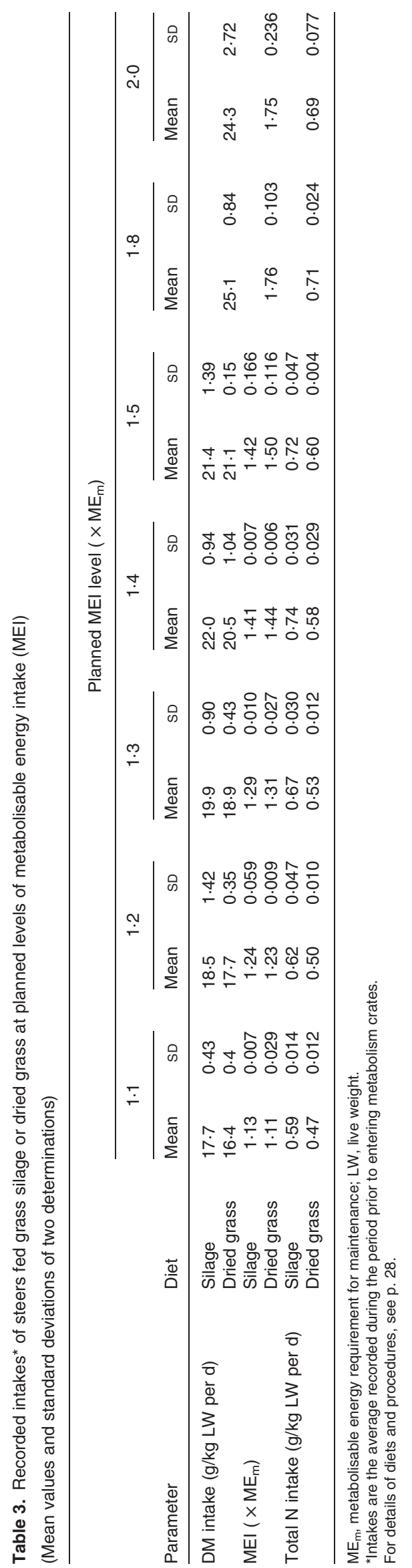


Table 4. Constants $(\alpha)$ and coefficients $(\beta)$ from the regression of performance data of steers fed either silage or dried grass $v$. metabolisable energy intake (MEI)

(Mean values with their standard errors)

\begin{tabular}{|c|c|c|c|c|c|c|c|c|c|c|c|}
\hline & \multicolumn{4}{|c|}{$\alpha$} & & & & & & & \\
\hline & \multicolumn{2}{|c|}{ Dried grass } & \multicolumn{2}{|c|}{ Silage } & \multicolumn{2}{|c|}{$\beta$} & \multirow[b]{2}{*}{$r^{2}$} & \multirow[b]{2}{*}{$\begin{array}{l}\text { RSD } \\
\text { (21 df) }\end{array}$} & \multicolumn{3}{|c|}{$P$ value } \\
\hline & Mean & SE & Mean & SE & Mean & SE & & & MEI & Diet & MEI.Diet†* \\
\hline \multicolumn{12}{|l|}{ Weights at slaughter } \\
\hline LW (kg)† & $57 \cdot 7$ & $14 \cdot 0$ & $54 \cdot 0$ & $12 \cdot 8$ & $50 \cdot 9$ & $9 \cdot 6$ & $59 \cdot 9$ & $9 \cdot 43$ & $<0.001$ & 0.385 & 0.993 \\
\hline LD $(g)$ & 1424 & 494 & 1058 & 449 & 982 & 337 & $46 \cdot 7$ & $332 \cdot 2$ & $<0.001$ & 0.021 & 0.397 \\
\hline $\mathrm{ST}(\mathrm{g})$ & 719 & 182 & 529 & 166 & 250 & 124 & $48 \cdot 8$ & $122 \cdot 7$ & 0.003 & 0.002 & $0 \cdot 183$ \\
\hline $\mathrm{KKCF}(\mathrm{g})$ & -905 & 242 & -759 & 221 & 1124 & 165 & $65 \cdot 8$ & $163 \cdot 1$ & $<0.001$ & 0.054 & 0.733 \\
\hline \multicolumn{12}{|l|}{ Daily gains $(g / d)$} \\
\hline $\mathrm{LW}$ & -320 & 96 & -371 & 87 & 531 & 66 & $79 \cdot 0$ & $64 \cdot 6$ & $<0.001$ & 0.083 & 0.653 \\
\hline Carcass weight & -168 & 61 & -229 & 55 & 281 & 41 & $77 \cdot 9$ & $40 \cdot 8$ & $<0.001$ & 0.002 & $0 \cdot 154$ \\
\hline Carcass CP & $-20 \cdot 2$ & $13 \cdot 1$ & -37.9 & 11.9 & $51 \cdot 2$ & 8.9 & $77 \cdot 4$ & $8 \cdot 79$ & $<0.001$ & $<0.001$ & 0.090 \\
\hline Carcass fat & $-60 \cdot 1$ & $13 \cdot 6$ & $-55 \cdot 7$ & $12 \cdot 4$ & $58 \cdot 2$ & $9 \cdot 3$ & $62 \cdot 4$ & $9 \cdot 18$ & $<0.001$ & 0.280 & $0 \cdot 701$ \\
\hline Carcass water & $-84 \cdot 3$ & 42.9 & $-132 \cdot 9$ & $39 \cdot 0$ & $161 \cdot 3$ & $29 \cdot 2$ & $73 \cdot 8$ & $28 \cdot 86$ & $<0.001$ & $<0.001$ & $0 \cdot 214$ \\
\hline Carcass energy $(\mathrm{MJ} / \mathrm{d})$ & $-2 \cdot 83$ & 0.75 & -3.06 & 0.68 & 3.47 & 0.51 & $71 \cdot 3$ & 0.501 & $<0.001$ & 0.294 & 0.341 \\
\hline \multicolumn{12}{|c|}{ Carcass composition at slaughter (g/kg carcass) } \\
\hline $\mathrm{CP}$ & $209 \cdot 5$ & $8 \cdot 1$ & $202 \cdot 1$ & $7 \cdot 4$ & -6.9 & $5 \cdot 6$ & $24 \cdot 8$ & 5.47 & 0.818 & 0.006 & 0.413 \\
\hline Fat & $16 \cdot 0$ & $14 \cdot 2$ & $30 \cdot 1$ & $13 \cdot 0$ & $42 \cdot 8$ & $9 \cdot 7$ & $48 \cdot 2$ & $9 \cdot 58$ & 0.002 & 0.003 & 0.661 \\
\hline Fat:protein & 0.06 & 0.07 & $0 \cdot 15$ & 0.06 & 0.23 & 0.05 & $56 \cdot 4$ & 0.047 & 0.002 & $<0.001$ & 0.460 \\
\hline Water & $712 \cdot 4$ & $19 \cdot 2$ & $700 \cdot 6$ & $17 \cdot 5$ & $-30 \cdot 4$ & $13 \cdot 1$ & $18 \cdot 8$ & $12 \cdot 92$ & 0.100 & 0.049 & 0.909 \\
\hline Ash & $56 \cdot 3$ & $4 \cdot 2$ & $62 \cdot 6$ & $3 \cdot 8$ & $-7 \cdot 1$ & $2 \cdot 9$ & $65 \cdot 5$ & $2 \cdot 81$ & $<0.001$ & $<0.001$ & 0.528 \\
\hline Energy (MJ/kg carcass) & 5.50 & 0.63 & $5 \cdot 88$ & 0.57 & 1.52 & 0.43 & $33 \cdot 3$ & 0.421 & 0.006 & 0.052 & 0.885 \\
\hline
\end{tabular}

RSD, residual standard deviation; LW, live weight; LD, longissimus dorsi; ST, semitendinosus; KKCF, kidney knob and channel fats; CP, crude protein.

*The MEl.Diet term was not included in the model that generated the rest of the data in this table.

†Final LW was predicted from the rate of LW gain prior to entering metabolism crates using linear regression.

For details of diets and procedures, see p. 28.

\section{Animal performance}

Daily LW gains and final LW increased $(P<0 \cdot 001)$ with increasing MEI (Table 4). Although not significant $(P=0 \cdot 083)$, animals fed grass silage had lower daily LW gains than animals fed dried grass, although this was not reflected by a dietary difference in final LW. This was not due to a dietary difference in the initial LW of the steers at the start of the experiment (96.0 (SD 7.95) v. 93.0 (SD $6.56) \mathrm{kg}$ for animals fed silage and dried grass, respectively).

Carcass and dissected tissue weights all increased $(P<0 \cdot 01)$ with increasing MEI (Table 4). Animals fed dried grass had significantly $(P=0.002)$ higher carcass weight gains than animals fed silage and, although not significant $(P=0.086)$, had heavier carcasses at slaughter. Animals fed dried grass had heavier longissimus dorsi (mean: 2.70 v. $2.33 \mathrm{~kg} ; \quad P=0.021$ ) and semitendinosis (mean: $1.04 \mathrm{v}$. $0.85 \mathrm{~g} ; P=0.002)$ muscles than animals fed silage at equivalent levels of MEI. Although not significant $(P=0 \cdot 054)$, the $\mathrm{KKCF}$ of animals fed grass silage was heavier than that of animals fed dried grass at equivalent levels of MEI (mean: $702 v$. $556 \mathrm{~g}$; Fig. 1). However, at ad libitum levels of MEI, animals fed dried grass had significantly $(P<0 \cdot 001)$ more KKCF than animals fed silage (1342 v. $927 \mathrm{~g})$.

Daily gains in carcass protein, fat, water and ash all increased significantly $(P<0 \cdot 01)$ with increasing MEI (Table 4). The response of carcass fat gain to MEI was reflected in carcass fat content, which also increased $(P=0.002)$ with increasing MEI. The increasing carcass fat content with increasing MEI presumably occurred at the expense of carcass ash content, which decreased $(P<0 \cdot 001)$ with increasing MEI, and carcass protein and water content, which were not affected by MEI. Daily rates of carcass protein and water gain were significantly $(P<0.001)$ lower in animals fed silage, resulting in carcasses that contained significantly less crude protein (mean: 193 v. $201 \mathrm{~g} / \mathrm{kg}$ carcass; $P=0.006$ ) and water (mean: $661 v .673 \mathrm{~g} / \mathrm{kg}$ carcass; $P=0.049$ ) than the carcasses of animals fed dried grass at equivalent levels of MEI. Despite the fact that there were no dietary differences in the daily rates of carcass fat, ash and energy gain, the carcasses of animals fed silage contained significantly more fat (mean: $86 v .72 \mathrm{~g} / \mathrm{kg}$ carcass; $P=0.003$ ) and ash (mean: 53 v. $47 \mathrm{~g} / \mathrm{kg}$ carcass; $P<0.001)$ and, although not significant $(P=0.052)$, they contained more energy (mean: $7.77 v$. $7.44 \mathrm{MJ} / \mathrm{kg}$ carcass) than the carcasses of animals fed dried grass at equivalent levels of MEI. The dietary differences in carcass fat and protein composition resulted in animals fed grass silage having significantly $(P<0.001)$ greater carcass fat:protein ratio than animals fed dried grass at equivalent levels of MEI (mean: 0.45 v. 0.36; Fig. 1). There were no significant differences $(P>0.05)$ in carcass fat and protein contents, and thus in the carcass fat:protein ratio, between animals fed ad libitum on silage and dried grass.

\section{Metabolism}

Fat metabolism. There was no effect $(P>0 \cdot 05)$ of diet on any of the rates of whole-body fat metabolism measured, i.e. 

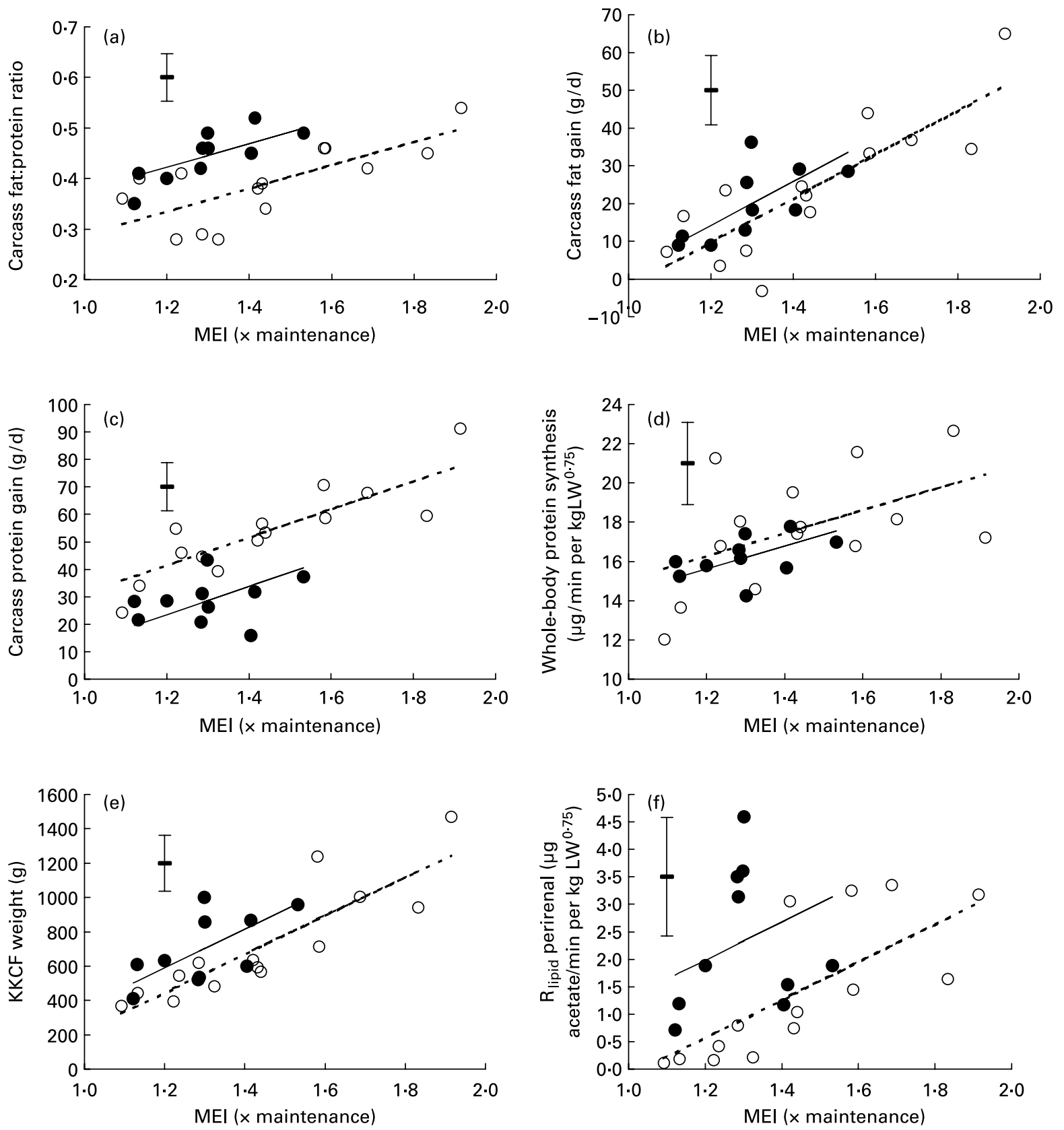

Fig. 1. The relationships between metabolisable energy intake (MEl; $\times$ maintenance) and carcass fat:protein ratio (a), carcass fat (b), protein gain (c), whole-body protein synthesis (d), kidney knob and channel fats weight (KKCF; e) and the rate of acetate incorporation into the total lipid of perirenal adipose tissue (f) in cattle fed grass silage $(\bullet)$ or dried grass $(O)$. Also shown are the lines through the silage $(-)$ and dried grass (---) data from the fitted model $Y=\alpha+\beta_{1} M E I+\beta_{2}$ Diet, the constants and coefficients of which can be found in Tables 4,5 and 6 . Values are means with the residual standard deviation shown by vertical bars $(21 \mathrm{df})$.

palmitate entry, palmitate oxidation and glycerol entry, or on plasma concentrations of NEFA and glycerol (Table 5). There was a significant $(P=0.033)$ effect of MEI on the rate of palmitate oxidation, which decreased with increasing MEI. Although not significant $(P=0 \cdot 055)$, plasma NEFA concentrations decreased with increasing MEI.

Rates of acetate incorporation into total lipid of all three adipose tissue depots measured increased $(P<0 \cdot 05)$ with increasing MEI (Table 6). The rate of acetate incorporation into the total lipid of perirenal adipose tissue was significantly $(P=0.007)$ greater in animals fed silage than in animals fed dried grass at equivalent levels of MEI (mean: 2.33 v. $0.91 \mu \mathrm{g}$ acetate/min per g lipid; Fig. 1). However, there was no difference $(P>0.05)$ between animals fed ad libitum on silage and dried grass, and no effect of diet on the rates of acetate incorporation into the total lipid of subcutaneous $(P=0.484)$ and omental $(P=0.398)$ adipose tissue.

Protein metabolism. Animals fed dried grass had significantly $(P<0.001)$ higher rates of leucine entry (mean: $10 \cdot 23 v$. $8 \cdot 37 \mu \mathrm{mol} / \mathrm{min}$ per $\mathrm{kg} \mathrm{LW}^{0 \cdot 75}$ ) and oxidation (mean: 3.00 v. $1.41 \mu \mathrm{mol} / \mathrm{min}$ per $\mathrm{kg} \mathrm{LW}^{0.75}$ ) and significantly $(P<0.001)$ higher plasma leucine concentrations 
Table 5. Constants $(\alpha)$ and coefficients $(\beta)$ from the regression of parameters of whole-body metabolism measured in steers fed either silage or dried grass $v$. metabolisable energy intake (MEI)

(Mean values with their standard errors)

\begin{tabular}{|c|c|c|c|c|c|c|c|c|c|c|c|}
\hline & \multicolumn{6}{|c|}{$\alpha$} & \multirow{2}{*}{$r^{2}$} & \multirow{2}{*}{$\begin{array}{c}\text { RSD } \\
\text { (21 df) }\end{array}$} & \multirow{2}{*}{\multicolumn{3}{|c|}{$P$ value }} \\
\hline & \multicolumn{2}{|c|}{ Dried grass } & \multicolumn{2}{|c|}{ Silage } & \multicolumn{2}{|c|}{$\beta$} & & & & & \\
\hline $\mathrm{RaCO}_{2}\left(\mu \mathrm{mol} / \mathrm{min}\right.$ per $\left.\mathrm{kg} \mathrm{LW} \mathrm{LW}^{0.75}\right) \dagger$ & 605 & 238 & 631 & 217 & 542 & 163 & $29 \cdot 7$ & $160 \cdot 5$ & 0.003 & $0 \cdot 718$ & 0.980 \\
\hline RaPalmitate $\left(\mu \mathrm{mol} / \mathrm{min}\right.$ per $\left.\mathrm{kg} \mathrm{LW} \mathrm{LW}^{0 \cdot 75}\right)$ & 1.68 & 0.52 & $1 \cdot 75$ & 0.47 & -0.44 & 0.35 & $2 \cdot 1$ & 0.349 & 0.149 & 0.62 & 0.324 \\
\hline RaGlycerol $\left(\mu \mathrm{mol} / \mathrm{min}\right.$ per $\mathrm{kg} \mathrm{LW} \mathrm{LW}^{0.75}$ ) & $8 \cdot 73$ & $3 \cdot 49$ & $9 \cdot 50$ & $3 \cdot 12$ & $4 \cdot 84$ & $2 \cdot 38$ & $8 \cdot 8$ & $2 \cdot 273$ & 0.072 & 0.479 & 0.227 \\
\hline RaAcetate $\left(\mu \mathrm{mol} / \mathrm{min} \text { per } \mathrm{kg} \mathrm{LW} \mathrm{LW}^{0.75}\right)^{\prime}$ & $21 \cdot 6$ & $55 \cdot 9$ & $38 \cdot 6$ & $50 \cdot 9$ & $151 \cdot 0$ & $38 \cdot 1$ & $37 \cdot 5$ & 37.62 & 0.001 & 0.316 & 0.116 \\
\hline RaLeucine $\left(\mu \mathrm{mol} / \mathrm{min}\right.$ per $\left.\mathrm{kg} \mathrm{LW} \mathrm{L}^{0.75}\right)$ & 4.91 & 1.47 & 3.04 & $1 \cdot 34$ & 4.09 & 1.00 & $68 \cdot 9$ & 0.987 & $\begin{array}{l}<0 \cdot 0- \\
01\end{array}$ & $\begin{array}{l}<0 \cdot 0- \\
01\end{array}$ & 0.488 \\
\hline $\begin{array}{l}\text { Leucine oxidation }(\mu \mathrm{mol} / \mathrm{min} \\
\left.\text { per } \mathrm{kg} \mathrm{LW^{0.75 }}\right)\end{array}$ & 0.96 & $0 \cdot 73$ & -0.63 & 0.66 & 1.57 & 0.50 & $79 \cdot 4$ & 0.489 & $\begin{array}{l}<0 \cdot 0- \\
01\end{array}$ & $\begin{array}{l}<0 \cdot 0- \\
01\end{array}$ & 0.558 \\
\hline Protein synthesis ( $\mathrm{g} / \mathrm{kg} \mathrm{LW} \mathrm{W}^{0.75}$ per $\left.\mathrm{d}\right)$ & $9 \cdot 20$ & $3 \cdot 12$ & $8 \cdot 57$ & $2 \cdot 84$ & $5 \cdot 88$ & $2 \cdot 13$ & $27 \cdot 0$ & $2 \cdot 101$ & 0.005 & 0.499 & 0.660 \\
\hline Plasma NEFA concentration $(\mu \mathrm{m})$ & $208 \cdot 3$ & $56 \cdot 7$ & $210 \cdot 0$ & $51 \cdot 6$ & $-72 \cdot 8$ & $38 \cdot 7$ & $8 \cdot 5$ & $38 \cdot 17$ & 0.055 & 0.921 & 0.176 \\
\hline Plasma leucine concentration $(\mu \mathrm{m})$ & $181 \cdot 0$ & $22 \cdot 9$ & $85 \cdot 5$ & $20 \cdot 8$ & $6 \cdot 3$ & $15 \cdot 6$ & $90 \cdot 8$ & $15 \cdot 41$ & $\begin{array}{l}<0 \cdot 0- \\
01\end{array}$ & $\begin{array}{l}<0 \cdot 0- \\
01\end{array}$ & 0.459 \\
\hline Plasma acetate concentration $(\mu \mathrm{m})$ & $627 \cdot 0$ & $145 \cdot 0$ & $444 \cdot 0$ & $132 \cdot 0$ & $268 \cdot 1$ & $99 \cdot 2$ & $60 \cdot 6$ & $97 \cdot 83$ & $\begin{array}{l}<0.0- \\
01\end{array}$ & $\begin{array}{l}<0 \cdot 0- \\
01\end{array}$ & 0.675 \\
\hline Plasma insulin concentration (U/ml) & $1 \cdot 05$ & $3 \cdot 24$ & $-2 \cdot 81$ & $2 \cdot 98$ & $4 \cdot 73$ & $2 \cdot 21$ & $54 \cdot 5$ & $2 \cdot 138$ & 0.002 & 0.001 & $1 \cdot 000$ \\
\hline
\end{tabular}

$\mathrm{RSD}$, residual standard deviation; Ra, entry rate.

${ }^{*}$ The MEI.Diet term was not included in the model that generated the rest of the data in this table.

†The calculation used to determine $\mathrm{RaCO}_{2}$ did not correct for $\mathrm{CO}_{2}$ sequestered in the body.

For details of diets and procedures, see p. 28.

Table 6. Constants $(\alpha)$ and coefficients $(\beta)$ from the regression of rates of acetate incorporation into the total lipid ( $\mathrm{R}_{\text {lipid, }} \mu \mathrm{g}$ acetate/min per $\mathrm{g}$ lipid) of different adipose tissue depots of steers fed silage or dried grass $v$. metabolisable energy intake (MEI)

(Mean values with their standard errors)

\begin{tabular}{|c|c|c|c|c|c|c|c|c|c|c|c|}
\hline \multirow[b]{3}{*}{ Depot } & \multicolumn{6}{|c|}{$\alpha$} & \multirow[b]{3}{*}{$r^{2}$} & \multirow[b]{3}{*}{$\mathrm{RSD}(21 \mathrm{df})$} & \multirow{2}{*}{\multicolumn{3}{|c|}{$P$ value }} \\
\hline & \multicolumn{2}{|c|}{ Dried grass } & \multicolumn{2}{|c|}{ Silage } & \multicolumn{2}{|c|}{$\beta$} & & & & & \\
\hline & Mean & se & Mean & se & Mean & se & & & MEI & Diet & MEI.Diet ${ }^{*}$ \\
\hline Subcutaneous & -10.03 & 2.08 & -9.61 & 1.86 & 8.89 & 1.40 & $66 \cdot 0$ & $1 \cdot 280$ & $<0.001$ & 0.484 & 0.467 \\
\hline Omental & -7.00 & 1.47 & $-6 \cdot 62$ & $1 \cdot 34$ & $6 \cdot 01$ & 1.00 & $60 \cdot 6$ & 0.990 & $<0.001$ & 0.398 & 0.434 \\
\hline Perirenal & -3.58 & $1 \cdot 61$ & $-2 \cdot 16$ & 1.46 & 3.46 & $1 \cdot 10$ & $34 \cdot 7$ & 1.081 & 0.033 & 0.007 & 0.392 \\
\hline
\end{tabular}

RSD, residual standard deviation.

*The MEI.Diet term was not included in the model that generated the rest of the data in this table.

For details of diets and procedures, see p. 28

(mean: 189.15 v. 93.66 $\mu \mathrm{M}$ ) than animals fed silage at equivalent levels of MEI (Table 5). There was no effect $(P=0.499)$ of diet on the rate of whole-body protein synthesis (Fig. 1). All parameters of protein metabolism measured increased $(P<0 \cdot 01)$ with increasing MEI.

Plasma acetate kinetics. Plasma acetate entry rate and plasma acetate concentration (Table 5) increased $(P<0.001)$ with increasing MEI. There was no effect $(P=0 \cdot 316)$ of diet on plasma acetate entry rate. However, animals fed silage had significantly $(P<0.001)$ lower plasma acetate concentrations than animals fed dried grass at equivalent levels of MEI (mean: 792.5 v. $975.9 \mu \mathrm{M}$ ). Consequently the calculated plasma acetate clearance rates for animals fed silage were significantly $(P=0 \cdot 004)$ greater than those calculated for animals fed dried grass at equivalent levels of MEI (mean: 239.5 v. $176.9 \mathrm{ml} / \mathrm{min}$ per $\mathrm{kg} \mathrm{LW}^{0.75}$ ). There was no difference in acetate clearance rate between animals fed ad libitum on silage and dried grass.

Plasma insulin concentration. Animals fed dried grass had significantly $(P=0.001)$ higher plasma insulin concentrations than animals fed silage (mean: $7 \cdot 19$ v. $3.33 \mathrm{U} / \mathrm{ml}$ ) at equivalent levels of MEI (Table 5). Plasma insulin concentrations increased $(P=0.002)$ with increasing MEI.

There were no significant interactions between MEI and diet for any of the parameters measured, i.e. there were no difference between the two diets in the responses to increasing MEI.

\section{Discussion}

The present experiment had two objectives. The first was to determine whether rates of fat accretion in cattle fed grass 
silage are higher than in cattle fed dried grass and thus whether this, together with impaired rates of protein accretion, contributes to the high carcass fat:protein ratio of cattle fed grass silage. The second objective was to determine whether or not responses to increasing MEI differ between grass silage and dried grass diets. To fulfil these objectives measures of fat and protein metabolism, using isotope dilution and incorporation techniques, were combined with measures of carcass composition in young growing cattle fed either grass silage or dried grass over a range of equivalent MEI levels.

Before discussing the results for the present experiment there are a number of points relating to the experimental design and methodology worth considering. First, the range of MEI fed was achieved by changing the amount of feed offered rather than by changing the composition of the diet. While this ensured that the proportion of nutrients in the diet remained unchanged, it did mean that MEI was not the only dietary component changed, and thus intake effects were not limited to ME. Second, the experiment relied on the assumption that metabolism, measured in animals confined to metabolism crates and fed hourly, reflects that responsible for carcass composition, which would have been largely defined by the growth period outside metabolism crates, during which time they were fed twice daily. It is acknowledged that the direct relevance of metabolism measurements made on hourly fed animals in practical production systems could be challenged (Thorp et al. 2000).

\section{Carcass composition}

The experiment confirmed that the carcasses of cattle fed grass silage do indeed have a high carcass fat:protein ratio. This was shown to be true when carcass fat:protein ratios of cattle fed grass silage were compared with those fed dried grass at equivalent levels of MEI. Interestingly, there was no difference in carcass fat:protein ratio between animals fed ad libitum on the two diets. This was attributable to the combined effects of the increase in fat:protein ratio with increasing MEI (Table 4) and the greater MEI of animals fed ad libitum on dried grass compared with grass silage (Table 3 ). This result may provide a plausible explanation as to why in some comparative carcass composition experiments, involving cattle fed grass silageand dried grass-based diets, no differences in carcass fat content have been reported, as these experiments did not use diets formulated to be isoenergetic (Steen \& Moore, 1988, 1989; Steen, 1991). Studies that have reported differences in carcass fat content between cattle fed silage-based diets and dried forage-based diets have all fed isoenergetic diets (Lonsdale, 1976; Moore \& Steen, 1983; Steen, 1991).

\section{Protein metabolism}

Clearly, a high carcass fat:protein ratio can be the result of a limited rate of protein deposition, an increased rate of fat deposition, or a combination of both. That protein deposition is limited in cattle fed grass silage is well established (Gill et al. 1987), and the performance data (Table 4) from the present experiment clearly support this, with cattle fed grass silage having lower daily carcass protein gains than cattle fed dried grass. However, there was no difference in rates of whole-body protein synthesis between the diets. If it is assumed that skeletal muscle accounts for a fixed proportion of whole-body protein synthesis, e.g. 20\% (Lobley, 1993), irrespective of diet and level of MEI, and that carcass protein is predominantly associated with skeletal muscle, then the ratio of carcass protein gain:synthesis in cattle fed grass silage was lower than that for cattle fed dried grass $(0.24$ (SD 0.06) v. 0.39 (SD 0.09), respectively; $P<0.001$ ), i.e. rates of carcass protein turnover were greater in cattle fed grass silage. However, this is unlikely as turnover rates are normally positively associated protein accretion rates (Lobley et al. 1987), and thus one would expect turnover rates to be greatest for the dried grass diet. In any case, where animals are fed different diets and at different levels of MEI, the assumption that skeletal muscle accounts for a fixed proportion of whole-body protein synthesis would be inappropriate. It has been suggested that a relationship between dietary fibre content and gut protein turnover exists (Seal \& Parker, 2000). While there was little difference in neutral detergent fibre concentration between the two diets, the grass silage contained approximately $6 \%$ more acid detergent fibre. It is therefore possible that gut protein turnover in cattle fed grass silage accounted for a larger proportion of the whole-body protein synthesis than in cattle fed the dried grass.

Based on the current understanding of the problem, i.e. the limited protein deposition in cattle fed grass silage, it was hypothesised that cattle fed grass silage would have had lower rates of whole-body protein synthesis. This is because amino acid intake and rates of protein synthesis have been shown to be positively related (Reeds \& Davis, 1992) - in cattle fed grass silage flows of duodenal amino acids have been shown to be limiting (Baker et al. 1985; Gill et al. 1987; Thomas \& Gill, 1988; Veira et al. 1994). Based on the lack of a dietary difference in the rate of whole-body protein synthesis, it might therefore be concluded that in the present experiment duodenal flows of amino acids were similar for the two diets. This is unlikely though, as the greater leucine entry and oxidation rates, and greater plasma leucine concentrations of animals fed dried grass (Table 5), are indicative of greater leucine absorption on this diet, as these parameters have been shown to be a function of intake (Meguid et al. 1986; Hammond et al. 1987; Lapierre et al. 2002; SavaryAuzeloux et al. 2003). This is supported by the effect of MEI, and thus protein intake as the relative composition of the diets remained unchanged, on these parameters associated with whole-body protein metabolism.

Based on the evidence of previous reports and the evidence of the present experiment, the limited rates of carcass protein gain, the lower plasma leucine concentration and the lower leucine entry and oxidation rates of cattle fed grass silage, it therefore seems likely that the result for rates of whole-body protein synthesis is misleading through failure to reveal a dietary difference. Based on the residual standard deviation $(2 \cdot 101)$ and degrees-of-freedom (21) for rates of protein synthesis (Table 5), it can be calculated that the least significant difference $(P=0.05)$ between two means required would have been $1.78 \mathrm{~g} / \mathrm{kg} \mathrm{LW}^{0.75}$ per d, i.e. a $10.5 \%$ difference. Where differences as small as $0.1 \%$ in the rate of protein synthesis can effect rates of tissue protein gains of $20-100 \%$ (Lobley, 1993), the sensitivity of the isotope dilution technique as used to measure rates of whole-body protein synthesis rates is clearly inadequate. 


\section{Fat metabolism}

Evidence to support the hypothesis that rates of fat accretion in cattle fed grass are elevated and thus contribute to the high carcass fat:protein ratios was inconclusive. There was no difference in the rate of carcass fat gain between animals fed grass silage and dried grass. The lack of a dietary difference in the rate of lipogenesis in adipose tissue from the subcutaneous depot, a depot associated with the carcass, corroborates this result. Thus, the higher concentration of carcass fat in cattle fed grass silage would appear to be due to the effect of the reduced rates of protein and water accretion on the proportions of the carcass constituents measured. The fact that young, growing animals were used in this experiment, combined with their overall relatively poor rates of LW gain (Table 4), could explain the lack of a dietary effect on rates of carcass fat gain. However, the reason for using young, growing animals was that it was in similarly aged animals that Lonsdale (1976) reported differences in carcass composition. Also, if rates of fat deposition were elevated in young animals then this could have important implications on animal mature size (Owens et al. 1993).

However, the experiment does provide evidence for elevated rates of fat accretion in non-carcass fat depots. There was a trend $(P=0.054)$ for cattle fed grass silage to have more KKCF than cattle fed dried grass, a result given credence by the higher rates of lipogenesis measured in adipose tissue from the perirenal depot. As for protein accretion, fat accretion is dependent upon the relative rates of lipogenesis and lipolysis and therefore an increase in the rate of lipogenesis does not necessarily infer an increase in the rate of fat accretion. However, the fact that there was this trend for a dietary difference in the KKCF weight, and that there was no difference in the rate of glycerol appearance, an index of lipolysis, suggest that the difference is indicative of an increased rate of fat accretion in this depot. Lonsdale (1976) similarly reported that dietary differences (silage $v$. silage plus dried grass diets) in fat deposition appeared to be more marked in non-carcass than carcass components in young cattle (approximately $110 \mathrm{~kg} \mathrm{LW}$ at slaughter).

It is possible that the result is a function of depot activity, depot activity being related to the stage of animal maturity. Carcass fat depots have been shown to be late-developing relative to non-carcass depots (Cianzio et al. 1985; Scollan et al. 2003). Therefore, it is tempting to speculate that had the animals been allowed to advance in maturity before slaughter, dietary differences in rates of carcass fat accretion may have been observed as they were for the perirenal depot.

Lonsdale (1976) proposed that elevated rates of fat accretion in cattle fed grass silage are the result of a limiting supply of amino acids for protein synthesis on this diet, with the consequent increase in energy available above maintenance stored as fat. This has been supported by experiments where reductions in carcass fat content have been achieved in cattle fed grass silage by increasing the duodenal supply of amino acids, through supplementation (Baker et al. 1985, 1992) and formaldehyde treatment (Thompson et al. 1981).

The principal energy substrate in ruminants is acetate. Animals fed grass silage had lower plasma concentrations of acetate than animals fed dried grass. Differences in circulating acetate concentrations normally arise through differences in rumen (Pethick et al. 1981) and endogenous acetate production (Cronjé et al. 1991). There was no dietary difference in acetate entry rate, yet animals fed grass silage had lower plasma acetate concentrations. This implies that animals fed grass silage had greater clearance rates (acetate disappearance rate, which under 'steady-state' conditions is assumed to equal acetate entry rate divided by plasma acetate concentration) of acetate than animals fed dried grass (239 (SD 61) v. 185 (SD 28) $\mathrm{ml} / \mathrm{min}$ per $\mathrm{kg} \mathrm{LW}^{0.75}$, respectively; $\left.P<0 \cdot 01\right)$. However, there is no obvious explanation for this.

\section{Insulin}

Hormones are important mediators of the effect of diet on growth and development. In the present experiment plasma insulin concentrations were measured. The increase in plasma insulin concentration with increasing MEI is consistent with the understanding that insulin status in ruminants is regulated by energy and amino acid supply (Lobley, 1992). The fact that animals fed dried grass had higher concentrations of insulin than animals fed grass silage at equivalent levels of MEI could indicate that there was a dietary difference in the duodenal supply of amino acids in the present study, as discussed earlier, although insulin release is believed to be more affected by propionate than amino acid absorption (Mineo et al. 1994; Gonda et al. 1997).

There was a significant correlation between plasma insulin concentration and both carcass protein gain $(r 0.722$, $P<0.001)$ and carcass fat gain $(r 0.475, P<0.05)$, which is consistent with insulin's role as a modulator of feed induced anabolic activity. Breier \& Gluckman (1991) suggested that the importance of insulin as a regulator of growth may be increased when nutrients for growth are limiting. In the present experiment there was no evidence of an effect of MEI on the significance of the correlation between insulin and carcass protein and fat gain. The strength of the correlation with carcass protein gain might suggest a greater role for insulin in directing protein metabolism than for fat metabolism. This suggestion is supported by the higher plasma insulin concentrations in animals fed dried grass, which had higher rates of protein gain than animals fed grass silage. Thorp et al. (2000) reported higher plasma insulin concentrations in cattle fed grass silage supplemented with barley, diets for which the group had previously reported reduced carcass fat: protein ratios, than cattle fed unsupplemented silage. Indeed, the role of insulin in directing fat metabolism in ruminants is uncertain; for example, Smith et al. (1992) were unable to demonstrate a correlation between insulin and fatty acid synthesis in vitro, while Mills et al. (1989) were able to.

The importance of the growth hormone/insulin-like growth factor I (IGF-I) axis as a major factor controlling postnatal growth and its interaction with nutritional status is well documented. Plasma growth hormone and IGF-I concentrations were not measured in the present experiment. However, circulating insulin concentrations have been shown to broadly correlate with circulating IGF-I concentrations (Dawson et al. 1998), and thus it is logical to speculate that animals fed dried grass might have had higher plasma IGF-I concentrations. IGF-I production is believed to be associated with the hepatic response to growth hormone, an association modulated by nutritional status (Brameld et al. 1996) and insulin 
(McGuire et al. 1995). As IGF-I is believed to mediate the protein anabolic effects of growth hormone (Douglas et al. 1991), it is likely that the greater rates of carcass protein gain in animals fed dried grass compared with grass silage were in part mediated by this hormone.

\section{Metabolisable energy intake}

The objective of feeding diets over a range of MEI was to determine whether there was an interaction between form of $\mathrm{ME}$, grass silage $v$. dried grass, and quantity of $\mathrm{ME}$, $1.1 \times \mathrm{ME}_{\mathrm{m}}$ to ad libitum, both of which are considered important determinants of animal performance (Beever et al. 1988; Thomas \& Gill, 1988; Steen, 1992; Steen \& Robson, 1995). As the overall efficiency of energy (Thomas \& Chamberlain, 1990) and amino acid (Beever et al. 1992; MacRae et al. 1995) utilisation of animals fed grass silage is considered to be poor, it was hypothesised that animals fed the different diets would respond differentially to changes in MEI. However, the lack of an interaction between diet and MEI for any of the parameters measured refutes this hypothesis. The fact that the ratio of dietary components remained constant irrespective of MEI may explain this result, as the inefficiencies in nutrient utilisation have been related to imbalances in nutrient supply (Beever et al. 1992).

The fact that linear regression best described the response to MEI for all the parameters measured indicates that there was no threshold requirement for MEI below which responsiveness was minimal. This is contrary to what has been reported by Smith et al. (1992), who did demonstrate the presence of a threshold requirement for MEI for in vitro adipose tissue anabolic activities, but not for in vivo measures of $\mathrm{N}$ metabolism. However, their range of MEI did include below maintenance requirement levels of MEI, whereas the present experiment did not.

With regard to the rates of acetate incorporation into the total lipid of subcutaneous, omental and perirenal adipose tissue per se, there did appear to be a differential response to MEI (Table 6). At low MEI acetate incorporation into lipid was greatest in perirenal adipose tissue, whereas at high intakes the greatest rates of acetate incorporation into lipid were measured in subcutaneous adipose tissue. Rates of acetate incorporation into the omental adipose tissue were low to intermediate at all levels of intake. This would imply that when nutrient supply is limiting non-carcass depots are favoured over carcass depots; in other words, that depotspecific metabolic activity is not only determined by the animal's stage of maturity, as mentioned earlier, but also by levels of nutrient supply. However, Broad \& Ulyatt (1980) reported no differences in the relative rates of in vivo lipogenic activity between depots in sheep fed at maintenance, $1.3 \times$ maintenance and ad libitum.

\section{Summary}

From the results of the present study it was concluded that the high carcass fat:protein ratios of young growing steers is the result of limited rates of protein accretion. While there was evidence that rates of non-carcass fat accretion were elevated in cattle fed grass silage, there was no evidence to support the hypothesis that, in cattle of the age used in the present experiment, elevated rates of carcass fat accretion contribute to the high carcass fat:protein ratio. The lack of any interaction between diet and MEI suggests that the efficiency of ME utilisation is dependent upon form, form including the source of the ME and ratio of ME relative to the other dietary components, rather than quantity.

\section{Acknowledgements}

The authors are grateful to J. B. Soar, C. P. Essex, F. M. Tye, D. Surgay, J. Corbett and J. Tweed for technical support. This work was funded by the Biotechnology and Biological Sciences Research Council (BBSRC).

\section{References}

Agriculture and Food Research Council (1993) Energy and Protein Requirements of Ruminants. An Advisory Manual Prepared by the AFRC Technical Committee on Responses to Nutrients. Wallingford, UK: CAB International.

Allsop JR, Wolfe RR \& Burke JF (1978) Tracer priming bicarbonate pool. J Appl Physiol 45, 137-139.

Baker RD, Young NE \& Laws JA (1985) Changes in body composition of cattle exhibiting compensatory growth and the modifying effects of grazing management. Anim Prod 41, 309-321.

Baker RD, Young NE \& Laws JA (1992) The effect of diet in winter on the body composition of young steers and subsequent performance during the grazing season. Anim Prod 54, 211-219.

Beever DE, Cammell SB, Thomas C, Spooner MC, Haines MJ \& Gale DL (1988) The effect of date of cut and barley substitution on gain and on the efficiency of utilization of grass silage by growing cattle 2. Nutrient supply and energy partition. Br J Nutr 60, $307-319$.

Beever DE, Dawson JM \& Buttery PJ (1992) Control of fat and lean deposition in forage fed cattle. In The Control of Fat and Lean Deposition, pp. 211-229 [PJ Buttery, KN Boorman and DB Lindsay, editors]. Oxford: Butterworth-Heinemann Ltd.

Brameld JM, Atkinson JL, Budd TJ, Saunders JC, Pell GRS \& Buttery PJ (1996) Expression of insulin-like growth factor-1 (IGF-1) and hormone-receptor (GHR) mRNA in liver, skeletal muscle tissue of different breeds of pig. Anim Sci 62, 555-559.

Breier BH \& Gluckman PD (1991) The regulation of postnatalgrowth - nutritional influences on endocrine pathways and function of the somatotropic axis. Livest Prod Sci 27, 77-94.

Broad TE \& Ulyatt MJ (1980) The effect of level of food intake on the incorporation of acetate into lipids and its distribution among various tissues in sheep. Br J Nutr 44, 71-79.

Calder AG \& Smith A (1988) Stable isotope ratio analysis of leucine and ketoisocaproic acid in blood plasma by gas chromatography/ mass spectrometry. Use of tertiary butyldimethylsilyl derivatives. Rapid Commun Mass Spectrom 2, 14-16.

Cianzio DS, Topel DG, Whitehurst GB, Beitz DC \& Self HL (1985) Adipose-tissue growth and cellularity - changes in bovine adipocyte size and number. J Anim Sci 60, 970-976.

Cronjé PB, Nolan JV \& Leng RA (1991) Acetate clearance rate as a potential index of the availability of glucogenic precursors in ruminants fed on roughage-based diets. Br J Nutr 66, 301-312.

Dawson JM, Greathead HMR, Craigon J, Hachey DL, Reeds PJ, Pell JM \& Buttery PJ (1998) The interaction between nutritional status and growth hormone in young cattle: differential responsiveness of fat and protein metabolism. Br J Nutr 79, 275-286.

Dawson JM, Greathead HMR, Sessions VA, Tye FM \& Buttery PJ (1999) Effect of gastric inhibitory polypeptide on bovine fat metabolism. Comp Biochem Physiol B Biochem Mol Biol 123, 79-88. 
Douglas RG, Gluckman PD, Ball K, Breier B \& Shaw JHF (1991) The effects of infusion of insulin-like growth-factor (IGF)-I, IGF-II, and insulin on glucose and protein-metabolism in fasted lambs. J Clin Invest 88, 614-622.

Food and Agricultural Organization (1970) Amino Acid Content of Foods and Biological Data on Proteins. Nutritional Studies no. 24. Rome: FAO.

Gibb MJ \& Baker RD (1992) The use of fish meal and monensin as supplements to grass silage and their effect on body composition changes in steers from 5 months of age to slaughter. Anim Prod 55, 47-57.

Gill M, Beever DE, Buttery PJ, England P, Gibb MJ \& Baker RD (1987) The effects of oestrdiol-17 $\beta$ implantation on the response in voluntary intake, live-weight gain and body composition, to fishmeal supplementation of silage offered to growing calves. J Agric Sci 108, 9-16.

Gonda HL, Lindberg JE \& Holtenius K (1997) Plasma levels of energy metabolites and pancreatic hormones in relation to the level of intake and intraruminal infusions of volatile fatty acids in fed wether sheep. Comp Biochem Physiol A Physiol 116, 65-73.

Greathead HMR, Dawson JM, Scollan ND \& Buttery PJ (2001) In vivo measurement of lipogenesis in ruminants using [1-C-14]acetate. Br J Nutr 86, 37-44.

Hachey DL, Patterson BW \& Reeds PJ (1991) Isotopic determination of organic ketoacid pentafluorobenzyl esters in biological fluids by negative chemical ionization gas chromatography/mass spectrometry. Anal Chem 63, 919-923.

Hammond AC, Huntington GB, Reynolds PJ, Tyrell HF \& Eisemann JH (1987) Absorption, plasma flux and oxidation of l-leucine in heifers at two levels of intake. J Anim Sci 64, 420-425.

Krishnamurti CR \& Janssens SM (1988) Determination of leucine metabolism and protein-turnover in sheep, using gas-liquid chromatography-mass spectrometry. Br J Nutr 59, 155-164.

Lapierre H, Blouin JP, Bernier JF, Reynolds CK, Dubreuil P \& Lobley GE (2002) Effect of supply of metabolizable protein on whole body and splanchnic leucine metabolism in lactating dairy cows. J Dairy Sci 85, 2631-2641.

Lobley GE (1992) Control of the metabolic fate of amino acids in ruminants: a review. J Anim Sci 70, 3264-3275.

Lobley GE (1993) Protein metabolism and turnover. In Quantitative Aspects of Ruminant Digestion and Metabolism, pp. 313-339 [JM Forbes and J France, editors]. Wallingford: CAB International.

Lobley GE, Connell A \& Buchan V (1987) Effect of food-intake on protein and energy-metabolism in finishing beef steers. $\mathrm{Br} J \mathrm{Nutr}$ 57, 457-465.

Lonsdale CR (1976) The effect of season of harvest on the utilisation by growing beef cattle of dried grass given alone or as a supplement to silage. PhD Thesis, University of Reading.

McDonald P, Henderson AR \& Heron SJE (1991) The Biochemistry of Silage, 2nd ed. Marlow: Chalcombe Publications.

McGuire MA, Dwyer DA, Harrell RJ \& Bauman DE (1995) Insulin regulates circulating insulin-like growth-factors and some of their binding-proteins in lactating cows. Am J Physiol Endocrinol Metab 32, E723-E730.

MacRae JC, Bruce LA \& Brown DS (1995) Efficiency of utilisation of absorbed amino acids in growing lambs given forage and foragebarley diets. Anim Sci 61, 277-284.

Matthews DE, Motil KJ, Rohrbaugh DK, Burke JF, Young VR \& Bier DM (1980) Measurement of leucine metabolism in man from a primed, continuous infusion of $1-\left[1-{ }^{13} \mathrm{C}\right]$ leucine. Am J Physiol Endocrinol Metab 238, E473-E479.

Matthews DE, Schwarz HP, Yang RD, Motil KJ, Young VR \& Bier DM (1982) Relationship of plasma leucine and $\alpha$-ketoisocaproate during a L- $\left[1-{ }^{13} \mathrm{C}\right]$ leucine infusion in man: a method for measuring human intracellular leucine tracer enrichment. Metabolism 31, $1105-1112$.
Meguid MM, Mathews DE, Bier DM, Meredith CN, Soeldner JS \& Young VR (1986) Leucine kinetics at graded leucine intakes in young men. Am J Clin Nutr 43, 770-780.

Mills SE, Lemenager RP \& Horstman LA (1989) Adipose tissue lipogenesis in growing steers adapted to different levels of feed intake. J Anim Sci 67, 3011-3017.

Mineo H, Hashizume Y, Hanaki Y, Murata K, Maeda H, Onaga T, Kato S \& Yanaihara N (1994) Chemical specificity of shortchain fatty acids in stimulating insulin and glucagon secretion in sheep. Am J Physiol 267, E234-E241.

Moore CA \& Steen RWJ (1983) The effect of silage- and hay-based diets and protein supplementation on the performance and carcass composition of beef cattle. Anim Prod 36, 514A.

Owens FN, Dubeski P \& Hanson CF (1993) Factors that alter the growth and development of ruminants. J Anim Sci 71, 3138-3150.

Pethick DW \& Dunshea FR (1993) Fat metabolism and turnover. In Quantitaive Aspects of Ruminant Digestion and Metabolism, pp. 291-311 [JM Forbes and J France, editors]. Wallingford: CAB International.

Pethick DW, Lindsay DB, Barker PJ \& Northrop AJ (1981) Acetate supply and utilization by the tissues of sheep in vivo. Br J Nutr 46, 97-110.

Reeds PJ \& Davis TA (1992) Hormonal regulation of muscle protein synthesis and degradation. In The Control of Fat and Lean Deposition, pp. 1-26 [PJ Buttery, KN Boorman and DB Lindsay, editors]. Oxford: Butterworth-Heinemann Ltd.

Savary-Auzeloux I, Hoskin SO \& Lobley GE (2003) Effect of intake on whole body plasma amino acid kinetics in sheep. Reprod Nutr Dev 43, 117-129.

Scollan ND, Dhanoa MS, Kim EJ, Dawson JM \& Buttery PJ (2003) Effects of diet and stage of development on partitioning of nutrients between fat and lean deposition in steers. Anim Sci 76, 237-249.

Scollan ND, Sargeant A, McAllan AB \& Dhanoa MS (2001) Protein supplementation of grass silages of differing digestibility for growing steers. J Agric Sci 136, 89-98.

Seal CJ \& Parker DS (2000) Influence of gastrointestinal metabolism on substrate supply to the liver. In Ruminant Physiology: Digestion, Metabolism, Growth and Reproduction, pp. 131-148 [PB Cronje, editor]. Wallingford: CABI Publishing.

Smith SB, Prior RL, Koong LJ \& Mersmann HJ (1992) Nitrogen and lipid metabolism in heifers fed at increasing levels of intake. J Anim Sci 70, 152-160.

Somogyi M (1945) Determination of blood sugar. J Biol Chem 160, 69-73.

Steen RWJ (1991) The effect of level of protein supplementation on the performance and carcass composition of young bulls given grass silage ad libitum. Anim Prod 52, 465-475.

Steen RWJ (1992) The effects of plane of nutrition and forage:concentrate ratio on the performance and carcass composition of steers. Anim Prod 54, 450A.

Steen RWJ \& Moore CA (1988) A comparison of silage-based and dried forage-based diets for finishing beef cattle. Anim Prod 47, 29-37.

Steen RWJ \& Moore CA (1989) A comparison of silage-based and dried forage-based diets, and the effect of protein supplementation of a silage-based diet for finishing beef cattle. Anim Prod 49, 233-240.

Steen RWJ \& Robson AE (1995) Effects of forage to concentrate ratio in the diet and protein-intake on the performance and carcass composition of beef heifers. J Agric Sci 125, 125-135.

Symonds ME, Bryant MJ \& Lomax MA (1989) Lipid metabolism in shorn and unshorn pregnant sheep. Br J Nutr 62, 35-49.

Thomas C \& Chamberlain DG (1990) Evaluation and prediction of the nutritive value of pastures and forages. In Feedstuff Evaluation, pp. 319-336 [J Wiseman and DJA Cole, editors]. London: Butterworths. 
Thomas C \& Gill M (1988) Principles of silage utilization and supplementation. In In Efficient Beef Production from Grass (Occasional Symposium no. 22, British Grassland Society), pp. 115-128, [J Frame, editor]. East Lothian: D. \& J. Croal Ltd. Thompson DJ, Beever DE, Lonsdale CR, Haines MJ, Cammell SB \& Austin AR (1981) The digestion by cattle of grass silage made with formic acid and formic acid-formaldehyde. Br J Nutr 46, 193-207.

Thorp CL, Wylie ARG, Steen RWJ, Shaw C \& McEvoy JD (2000) Effects of incremental changes in forage:concentrate ratio on plasma hormone and metabolite concentrations and products of rumen fermentation in fattening beef steers. Anim Sci 71, 93-109.

Veira DM, Butler G, Proulx JG \& Poste LM (1994) Utilisation of grass-silage by cattle - effect of supplementation with different sources and amounts of protein. J Anim Sci 72, 1403-1408.

Wolfe RR, Evans JE, Mullany CJ \& Burke JF (1980) Measurement of plasma free fatty acid turnover and oxidation using $\left[1-{ }^{13} \mathrm{C}\right]$ palmitic acid. Biomed Mass Spectrom 7, 168-171. 